\title{
The Strategy for Implementing Agricultural Extension Based on Cyber Extension in Malang Raya Region, Indonesia
}

\author{
Sabir $^{1 *}$, Sugiyanto ${ }^{2}$, Keppi Sukesi², Yayuk Yulianti ${ }^{2}$ \\ ${ }^{1}$ PhD Student, Doctoral Program of Agricultural Science, University of Brawijaya, Malang, Indonesia \\ ${ }^{2}$ Lecturer, Doctoral Program of Agricultural Science, University of Brawijaya, Malang, Indonesia
}

Received: 4 December 2018; Revised: 13 December 2018; Accepted: 29 January 2018

\begin{abstract}
This study aimed to formulate a strategy for implementing agricultural extension based on cyber extension in Malang Raya region. This research was conducted in Malang raya region using purposive sampling technique. The analysis used to determine strategy priority for implementing agricultural extension used SWOT analysis. Based on internal analysis (IFAS) and external analysis (EFAS) implied that the position of cyber extension utilization by agricultural extension workers in the Malang Raya Region was in the area of strategy I, namely Aggressive Strategy. This depicted that the strength possessed can take advantage of opportunities and improve weaknesses optimally, so the determination of the strategy for optimizing the use of cyber extensions was more directed at aggressive strategies. Based on this study showed that the measures should be implemented such as the implementation of legislation has the greatest contribution, optimization of the utilization of information technology devices, optimization of utilization of the agricultural extension centre in each sub-district, and increasing competency and the professionalism of administrators in accordance with their respective duties and authorities.
\end{abstract}

Keywords: cyber extension; agriculture extension; SWOT

\section{How to Cite:}

Sabir, S., Sugiyanto, S., Sukesi, K., \& Yulianti, Y. (2019). The Strategy for Implementing Agricultural Extension Based on Cyber Extension in Malang Raya Region, Indonesia. HABITAT, 30(1), 8-15. https://doi.org/10.21776/ub.habitat.2019.030.1.2

\section{Introduction}

Agricultural extension worker is the spearhead of agricultural development in Indonesia which plays a strategic role towards the success of agriculture development. This happens because the agricultural extension worker should deal directly with both the farmers/farmer groups and the large community (Kim, et al., 2017). To support the implementation of agricultural counseling to be effective and efficient it is necessary to increase the knowledges and skills for agricultural extension workers.

Entering this 4.0 development era, the implementation of counseling has to be consistent with the rapid deterioration of information, communication, science and technology. To achieve the goal of counseling is necessary supported by a strong information

\footnotetext{
*) Penulis Korespondensi.

E-mail: sabirtato@gmail.com

Telp: +62-82141353434
}

system and clear, so that the acceleration of information can be on time, right place, and right target. Related to this matter, the Ministry of Agriculture through the Agency for Extension and Development of Agricultural Human Resources (BPPSDMP) modifies the preparation and dissemination of information on agricultural extension through the network connected to the internet called cyber extension (Badan PPSDMP, 2010). Cyber extension is an agricultural information exchange mechanism through the cyber area, an imaginary space - virtual behind network interconnection computer through communication equipment (Sumaryo, et al., 2017). Cyber extension may empower agricultural extension workers through preparation of timely and relevant agricultural information in supporting decision making process to deliver information to the farmers (Helmi, et al., 2013).

The cyber extension is a vital machinery to support the extension functionaries. Availability of information over internet assists the process of 
agricultural extension and makes it speedy and more effective (Ahuja, 2011). The cyber extension comunication model collects or concentrates information received by farmers from various different sources or the same and simplified in local languages accompanied by text and audio-visual illustrations that can be presented or shown to the whole community villages especially farmers (Sumardjo, et al. 2010).

The existence of cyber extensions bring consequences and demands to agriculture extension worker to be more proactive looking for information and counseling material needed by extension workers, rather than just waiting for the delivery of counseling materials agriculture from the government. But on the other hand extension workers in Malang Raya still relies on print media as a source of information for activities counseling. Information from internal is not chosen as a source of information, even though extension workers are required to follow the developments of science and technology, besides that, information needed by the farmers more diverse and site-specific.

Lack of knowledge of agricultural extension workers to apply technology and access the internet, while according to Ahuja (2011) availability of information through the internet helps the counseling process of agricultural more quick and effective. The amount of information that is easily accessed quickly and cheap can be utilized by the workers to increase knowledge, so that it can improve its performance (Gunawan, 2013). Gultom (2017) reviewing the use of cyber extension as a strategy to fulfill the information needs of agriculture in Lampung province. Cyber extension is also used as a communication media model to strengthen horticulture farmers in facing globalization in Lampung province (Gultom et al. 2016).

Some research results show that the performance of agricultural extension worker based cyber extension is still very low. The problem faced by stakeholders in implementing cyber extension is management, infrastructure / facilities of human resource, and culture (Wicaksono, 2016; Mulyandari et al. 2010). According Helmy et al., (2014) the strategy of cyber extension in strengthening the readiness of the extension workers was carried out by publishing regulations that control the management system of agricultural information that includes aspects of planning, organization, costing, facilities and infra-structure, monitoring and evaluation.

Related to this matter necessary research related to strategy for implementing agricultural extension based cyber extension in Malang Raya region. For this reason, the purpose of this research is formulating a strategy for implementing agricultural extension based cyber extension in Malang Raya region.

\section{Research Method}

The research was conducted in Malang Raya region and the sample determination was taken purposively by using purposive sampling techniques. The respondent sample in this research consists of 15 people agricultural extension workers in Malang Raya region.

Table 1. Respondent Sample

\begin{tabular}{clc}
\hline No & \multicolumn{1}{c}{ Sample } & $\begin{array}{c}\text { Number } \\
\text { of } \\
\text { Sample } \\
\text { (People) }\end{array}$ \\
\hline 1. & $\begin{array}{l}\text { Cyber extension administrator } \\
\text { 2he coordinator of provincial }\end{array}$ & 1 \\
3. $\begin{array}{l}\text { The coordinator of Malang } \\
\text { regency extension worker }\end{array}$ & 3 \\
4. $\begin{array}{l}\text { Agriculture extension centre } \\
\text { of Malang regency }\end{array}$ & 2 \\
5. Animal & $\begin{array}{l}\text { Department of } \\
\text { Husbandary worker } \\
\text { Agriculture extension worker } \\
\text { of Malang city } \\
\text { Agriculture extension worker } \\
\text { of Batu city }\end{array}$ & 1 \\
Total & 4 \\
\hline
\end{tabular}

The types of data collected in this research includes primary data and secondary data. Primary data obtained from respondent sample, while secondary data is obtained from documents on extension activites at Malang Raya Region.

Data collection techniques by observation, documentation, interviews and Focus Group Discussion (FGD). While quantitative data collection using questionnaire distributed to respondents selected. To determine the priority of development strategy for the role of agricultural extension workers using SWOT analysis. According to Wanti et.al., (2014) SWOT analysis is an important strategic planning tool to help plan for comparing internal strengths and weaknesses with opportunities and threats from external. SWOT analysis is an identification of 
various factors systematically to formulate a corporate strategy. This analysis based on logic that can maximize strengths and opportunities, but simultaneously can minimize weaknesses and threats (Rangkuti, 2015).

In this research identification was carried out variables which are strengths and opportunities that are used using likert scale on five levels consist of: excellent (5), good (4), fair (3), less (2), bad (1). Variable strengths described by government regulation, education level, proprietary of information technology device and existency of agricultural extension center in each district. Variable opportunities described by special website address, information, accessibility, the existence of agricultural extension centre and the existence of other cyber application. Then this research continued with identification of variables which were weaknesesses and threats from outside. Variable weaknesesses consists of agricultural extension workers skill using technology,administrator behaviour, infrastructure and signal range. Variable threats described by cost, information, cyber crime, law and communication, and information technology.

\section{Results and Discussion}

\subsection{The analysis of strategy for implementing agricultural extension based on cyber extension}

In an effort to maximize utilization of cyber extensions in agricultural extension activities especially in Malang Raya region is deemed necessary consider various factors, both relating to internal conditions and external environment known as Strenghts, Weaknessess, Opportunities, Threats (SWOT).

SWOT analysis is one of analysis that has a role to establish effective strategies by utilizing opportunities or opportunities based on strengths and solve the threats by solving existing weaknesses.

\subsection{Internal Analysis Matrix}

The internal factors include strengths and weaknesses that have been identified, arranged in a matrix. IFAS (internal strategic factor analysis summary). The results of internal strategy analysis implementing agricultural extension based cyber extension in Malang Raya region is presented in Table 2.

Table 2. Internal Analysis of Implementing Agricultural Based Cyber Extension in Malang Raya Region

\begin{tabular}{|c|c|c|c|c|}
\hline No & Environmental Analysis & Weight & Rating & Skor \\
\hline 1 & 2 & 3 & 4 & $5(3 \times 4)$ \\
\hline \multicolumn{5}{|c|}{ Internal Environmental Analysis } \\
\hline \multirow[t]{6}{*}{ A } & Strength $(\mathrm{S})$ & & & \\
\hline & 1 UU No.16 at 2016 & 19,15 & 3 & 0,57 \\
\hline & 2 Permentan No. 16 at 2013 & 19,15 & 3 & 0,77 \\
\hline & 3 Education level of extension worker & 8,51 & 4 & 0,34 \\
\hline & $\begin{array}{l}4 \text { Proprietary of Information Technology Device of } \\
\text { extension worker }\end{array}$ & 4,26 & 4 & 0,17 \\
\hline & $\begin{array}{l}5 \text { Agricultural extension centre is in each district } \\
\text { Sub Amount }\end{array}$ & 4,26 & 3 & $\begin{array}{l}0,13 \\
\mathbf{1 , 9 8}\end{array}$ \\
\hline \multirow[t]{9}{*}{ B } & Weakness (W) & & & \\
\hline & 1 Agricultural extension workers stutter for technology & 14,6 & 4 & 0,58 \\
\hline & 2 Unprofessional administrator & 12,5 & 3 & 0,37 \\
\hline & 3 Limitations of facilities and infrastructures & 10,4 & 3 & 0,31 \\
\hline & 4 It has not optimized any institutions yet & 6,3 & 1 & 0,06 \\
\hline & 5 Weak signal & 6,3 & 2 & 0,13 \\
\hline & Sub Amount & & & 1,45 \\
\hline & Total Internal & & & $\mathbf{3 , 4 2}$ \\
\hline & Internal Variance $(\mathrm{S}-\mathrm{W})$ & & & $\mathbf{0 , 5 3}$ \\
\hline
\end{tabular}

The results of internal analysis in Table 2 show that the score weights of the strength are 1.98 and the score weights of the weakness are 1.45. Based on these results obtained intenal variance (strength and weakness) are 0.53 . This means that internally, the condition of the agricultural extension workerss in Malang Raya region have more dominant in strength than weakness, or in other words that internally extension workers have better potential in an 
effort to increase implementing agricultural extension based cyber extension. According to Helmi et al., (2014) showed that the agricultural extension workers in the two locations, namely the Regency of Bekasi and the Regency of Kuningan were not ready to utilize cyber extension as one of the model alternatives of agricultural extension system. This is because the extension workers were not yet able to operate the computer and to utilize internet, which became the basis of cyber extension utilization. The government extension workers in the Regency of Bekasi and the Regency of Kuningan whose age was not relatively young, nearly retired, even tended to avoid using cyber extension for the agricultural extension system.

In line with Pramono, et al., (2017) the use of the smartphone is expected to increase the knowledge of extension workers with various sources of agricultural information from the internet, and is ready to be transferred to the farmers. Therefore, although they do not have much experience, then the role of smartphones or laptop can help them to improve their insight and competence in absorbing better information. In Garut, the skill of extension workers is generally in the low category. To solve these problems, the extension workers are expected to be able to access cyber extension and utilize it to support knowledge transfer (Fangohoi, et al., 2018).

Weaknesses occur in accordance with the statement of the Head of the Agricultural Extension Center about the limited number of cyber-extention visitors that have not yet been standardized. The cyber extension hardware has not been integrated with other agricultural information and technology providers such as Katam, Landsat, e-farms, etc. information technology (IT) is still low, the appearance of cyber extensions is less attractive and the contents are not in accordance with the needs of the field, signals in some places at certain hours are very weak because users exceed capacity (overload), administrators are less professional and often change people even abolished.

According to Marliati et al., (2008), the potential for implementing cyber extension should be used by extension workers. Moreover, extension workers are currently demanded not only to be able to change the behavior of farmers but also to increase food production. Therefore, the importance of this role causes extension workers to be required to have high competence. competency of agricultural extension workers is one of the main factors that is expected to have an influence on their performance.

\subsection{External Analysis Matrix}

The external factors include opportunities and threats that have been identified, arranged in a matrix EFAS (external strategic factor analysis summary). The results of strategy analysis implementing agricultural extension based cyber extension in Malang Raya region is presented in Table 3.

Table 3. External Analysis of implementing Agricultural Extension Based Cyber Extension in Malang Raya region

\begin{tabular}{|c|c|c|c|c|}
\hline No & Environmental Analysis & Weight & Rating & Skor \\
\hline 1 & 2 & 3 & 4 & $5(3 \times 4)$ \\
\hline \multicolumn{5}{|c|}{ External Environmental Analysis } \\
\hline \multirow[t]{7}{*}{ A } & Opportunities $(\mathrm{O})$ & & & \\
\hline & 1 Special website address for cyber extensions & 20 & 4 & 0,80 \\
\hline & 2 Information needed by the extension workers & 20 & 4 & 0,80 \\
\hline & 3 Accessibility is relatively easy & 13,3 & 3 & 0,40 \\
\hline & $\begin{array}{l}4 \text { The existence of training and research and development } \\
\text { institutions }\end{array}$ & 11,1 & 2 & 0,22 \\
\hline & 5 The existence of other cyber application & 8,9 & 1 & 0,09 \\
\hline & Sub Amount & & & 2,31 \\
\hline \multirow[t]{7}{*}{ B } & Threat $(\mathrm{T})$ & & & \\
\hline & 1 Increased operational costs & 15,6 & 4 & 0,62 \\
\hline & 2 Fake reporting (hoax) & 6,7 & 3 & 0,20 \\
\hline & 3 Cyber crime & 4,4 & 2 & 0,09 \\
\hline & 4 Violation of law and communication ethics & 2,2 & 1 & 0,02 \\
\hline & 5 Damage to TI facilities & 0 & 1 & 0,00 \\
\hline & Sub Amount & & & 0,93 \\
\hline
\end{tabular}


Total Internal

The results of external analysis as shown in Table 3 shows that opportunity factors has a score weight of 2.31 while the threat factors has a score weight of 0.93 . Thus, the results of the external analysis shows the variance between opportunity and threat factors are 1.38. That means that implementing agricultural extension workers based cyber extension in Malang Raya region has a better chance compared to threats in an effort increased utilization of implementing agricultural extension based cyber extension.

The results of interviews conducted by several agricultural extension workers who use cyber extension generally only searched for and download material through cyber extension and other agricultural cyber media, but have never sent information and technology through cyber extension. This is an opportunity that can be utilized by agricultural extension workers, especially in terms of accessibility to cyber extensions, the use of cyber extension information content as material for agricultural extensions to the main actors and business actors. While the absencethe absence of an operational access to cyber extension budget can increase operational costs and only the start of support from our government in the use of cyber extension, fake reporting (hoax), cyber crime, violation of law and communication ethics, damage to TI facilities, this can make a factor threat in the strategy for implementating cyber extension.

In line with Purwatiningsih et al., (2018) Financial support for internet access falls into the low category. Extension workers rarely get special fees for internet access from agencies, so that to meet the cost requirements of internet access extension agents must provide themselves, even though supporting factors such as funding from these agencies are very important because it will affect the level of internet optimalization.

Based on the score known that IFAS value is positive, that is equal to 0.53 and EFAS value is also positive that is equal to 1.38 . This shows that the strengths are more greater than the weakness, and the opportunities are still able to overcome the threats. From this description, a strategy can be developed that could be used as a factor in the success of cyber extensions utilization as a media for agricultural extension in the Malang Raya region.The results of the scores of each IFAS and EFAS analysis can be mapped as below:

ALE

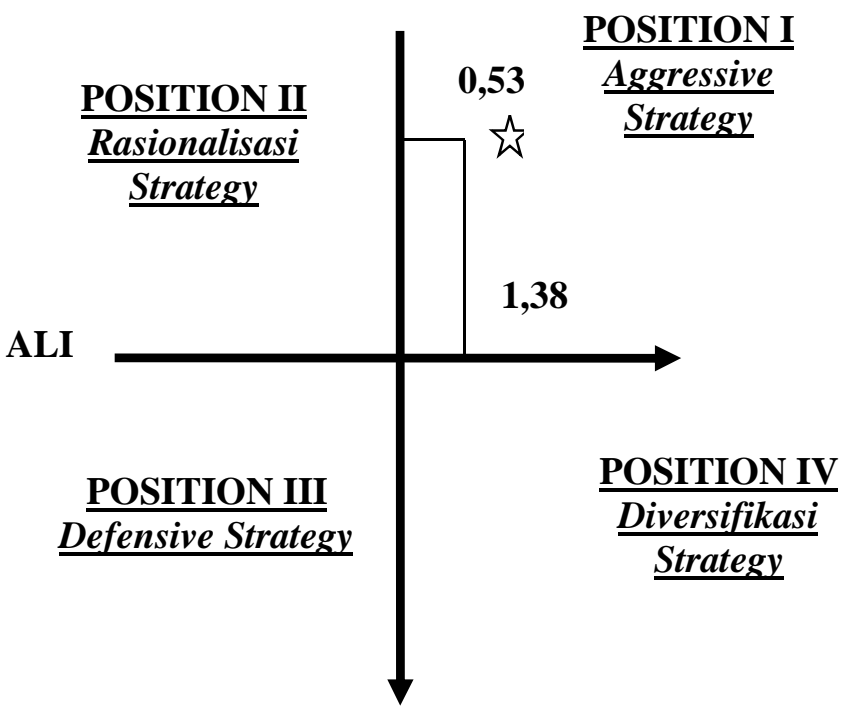

Figure 1. Determining the Position of Strategy Use of Cyber Extensions

Based on the results of the mapping above it is known that use of cyber extension position by agricultural extension workers in Malang Raya region is in the strategy I area is Aggressive Strategy. This matter indicates that strength can take the advantage of opportunities and fix the weaknesses maximally, so that the optimization strategy is determined to the utilization of cyber extensions directed at aggressive strategies.

Based on the results of descriptive analysis and SWOT analysis, then utilization strategy of cyber extensions is Aggressive Strategy by maximizing the power to take advantage of opportunities that has some elements consist of Implementation of the Law Number 16 / Agricultural Minister Regulation / OT.140 / 2/2013 about Information Management System Guidelines of Agricultural Extension, Implementation of Agricultural Minister Regulation No. 47 / Agricultural Minister Regulation / SM.010 / 9/2016 about Guidelines for Preparation of Agricultural Extension Programs, there is Maximizing utilization of information technology devices by agricultural extension workers are laptop, tab or android to access cyber extensions, encourage UPT BP or 
PPK to intensify the use of cyber extension, improve competence of agricultural extension, improve competence and professionalism of cyber extension administrator complete the facilities information and communication infrastructure at each UPT BP or at the Counseling Center Agriculture District (PPK). Based on the description, so arranged a urgency ratio from Implementation of Legislation and Agricultural Minister Regulation.

\section{a. Implementation of Legislation}

Based on the results of the SWOT analysis obtained the highest strength score of 0.77 which gives meaning that implementation of legislation has the biggest contribution compared to the other factors. For this reason, implementation of legislation and Agricultural Minister Regulation needed that regulates operations of implementing agricultural extension to be a rule area, so every policy and implementation of extension in the area become more consistent.

The form organization of implementing agricultural extension workerss must more professional is a system oriented extension institutions only for the sake of interest agricultural extension, free conflicts of community interests, both from the central level or region.

This is according to Harsoyo and Subejo (2012) agricultural strategies in Indonesia need to be oriented on the application of "segmented client oriented approach". Needs to chage the mindset from central and local bureaucracies, this also needs to be encouraged so they become more pro against agricultural extension policy.

\section{b. Optimization the Use of Information Technology Devices}

Optimizing the use of information technology devices of agricultural extension workers needed efforts to increase knowledge and skills of them through some activities include technical training or guidance, especially in accessing information technology agriculture through cyber extensions. And in order to guarantee the availability of internet data package quota it is deemed necessary to help package costs data for each agricultural extension worker through regional government budget allocation or center.

\section{c. Optimization the Use of UPT BP}

Hall Technical Implementation Extension Unit (UPT BP) is an agricultural counselling institution at the sub-district level which is operationally carrying out the function as a center of agricultural information and technology at the sub-district level.

In an effort to optimize the role and its function as an agricultural information center and technology, each UPT BP need to complete the facilities and infrastructure and special competent and professional administrator and sufficient routine operational costs.

\section{d. Increasing Competency and Profesionalism of Cyber Extension Administrator}

Administrator is someone who is specifically given an assignment and authority to manage cyber extensions according to position or level. In implementing Minister Regulation Agriculture No. 16 / Agricultural Minister Regulation/OT.140/2/2013 about the guidelines of management system of agricultural extension information that the cyber extension workers / administrator consists of the central administrator, field administrator, sub sector administrator, provincial administrator, district / city administrator and administrator BP3K / district level with assignments and their respective authorities.

\section{Conclusion}

The priority of the strategy for implementing agricultural extension based cyber extension in Malang Raya region is implementation of legislation that has the greatest contribution, optimization of the use information technology device, optimization the use of the Hall Technical Implementation Extension Unit (UPT BP) in each sub-district, and improve the competence and professionalism of cyber administrators extension according to the assignment and their respective authorities. Some efforts have been made by agricultural extension centre region in optimizing the use of cyber extension for agricultural extension workers by facilitating the agricultural cyber extension centre with cyber extension devices like computer, telephone networks or Base Transceiver Station (BTS), socializationof the use of cyber extension to extension worker through regular meetings at UPT, and provision of a budget for the payment of telephone usage fees. So, cyber extension would be effective if they have relative strong regulation, availability of technological device, as well as dynamics organization has focus on coordinating extension activities, monitoring, and evaluation processes. 


\section{References}

Ahuja, V. 2011. Cyber Extention: A Convergence of Ict and agricultural Development. Global Media JournalIndian Edition. 2 (2): 1-8.

Badan PPSDMP. 2010. Grand Design Sistem Informasi Penyuluhan Pertanian (Cyber Extension). Badan Penyuluhan dan Pengembangan SDM Pertanian. Kementerian Pertanian.

Gultom. D. T., Sumardjo, Sarwoprasojo S, Muyono. Pudji M. 2017. Strategi Pemenuhan Kebutuhan Informasi Pertanian Melalui Pemanfaatan Cyber Extension Di Propinsi Lampung. Jurnal Sosiohumaniora. Volume 19 No. 1 Maret 2017 : pp. 64-69.

Gultom, D. T., Sumardjo., Sarwoprasojo, S., Muyono. Pudji, M., 2016. The Roles of Cyber Extention Communication Media in Strengthening Horticulture Farmers in Facing Globalization in Lampung Province, Indonesia. International Journal of Sciences: Basic and Applied Research (IJSBAR) vol 42 (3) 104-117.

Fangohoi, L., Sugiyanto., Sukesi, K., \& Cahyono, E. D. 2018. Establish The Perception Of Agricultural Extension workers Through Cyber Extension As The Media Information. Journal of Socioeconomics and Development. Vol 1 (1). pp. 32-37

Harsoyo dan Subejo. 2012. Keterkaitan Isu Pembangunan Pertanian dan Pedesaan Kontemporer dengan Pendidikan Sosiologi dan Penyuluhan Pertanian. Makalah Lokakarya Nasional. 145-154.

Helmi, Z., Sumardjo., Purnaningsih, N., Tjitropranoto, P. 2014. Cyber Extension in Strengthening the Extension Workers' Readiness in the Regencies of Bekasi and Kuningan, West Java Province. International Journal of Sciences: Basic and Applied Research (IJSBAR) Vol 8 (1) :56-66.

Helmi, Z., Sumardjo., Purnaningsih, N., Tjitropranoto, P. 2013. Hubungan Kompetensi Penyuluh dengan Karakteristik Pribadi, Persepsi Penyuluh Terhadap Dukungan Kelembagaan dan Persepsi Penyuluh Terhadap Sifat Inovasi
Cyber Extensión. Jurnal agro Ekonomi Vol 31(1):1-18.

Kim, J. M., Jeon, Y. U., Lim, J. H., \& Yoo, Y. J. (2017). The Needs of Customer to Agricultural Extension Service and the Performance Level of Public Agricultural Extension Organization. Journal of Agricultural Extension and Community Development

Marliati., Sumardjo., Pang S. Asngari., Tjitropranoto, P., Saefuddin. A,. 2008. Faktor-Faktor Penentu Peningkatan Kinerja Penyuluh Pertanian Dalam Memberdayakan Petani (Kasus di Kabupaten Kampar Provinsi Riau). Jurnal Penyuluhan. Vol 4(2), pp. 92-99.

Mulyandari, R.S. H., Sumardjo., Lubis, DP., Panjaitan, NK. 2010. Implementasi Cyber Extension Dalam Komunikasi Inovasi Pertanian. Jurnal Informatika Pertanian. Vol 19 (2). 19-43.

Pramono, H., Fatchiya, A., dan Sadono, D. 2017. Kompetensi Penyuluh Tenaga Harian Lepas Tenaga Bantu Penyuluh Pertanian di Kabupaten Garut, Jawa Barat. Jurnal Penyuluhan.13(2): 194-209

Purwatiningsih, N.,A, Fatchiya, A.,Mulyandari, R.,S.,H. 2018. Pemanfaatan Internet dalam Peningkatan Kinerja Penyuluh Pertanian di Kabupaten Cianjur. Jurnal Penyuluhan. Vol 14 (1). 79-91.

Rangkuti, Freddy. 2015. Analisis SWOT: Teknik Membedah Kasus Bisnis. Gramedia Pustaka Utama. Jakarta.

Sumardjo., Baga., dan Mulyandari, 2010. Cyber Extension Peluang dan Tantangan Dalam Revitalisasi Penyuluhan Pertanian. IPB Press. Bogor.

Sumaryo, Kordiyana K., Rangga. 2017. Implementasi Cyber Extension Dalam Pengembangan Sumberdaya Manusia Pertanian: Kendala Yang Dihadapi DI Provinsi Lampung. Seminar Nasional IIB Darmajaya. Pp. 296-307.

Wanti, S. Taufiqurrahman., D.D. Rahayu. 2014. Analisis Strategi Keunggulan Bersaing Dengan Pendekatan Analisis SWOT pada Spartan Gym Pekanbaru. JOM Vekon 1(2). 
Wicaksono, P., Sugiyanto, S., Purnomo, M. (2016). Faktor-faktor yang berkontribusi terhadap kinerja dan kompetensi penyuluh pertanian pada jenjang jabatan penyuluh pertanian ahli (kasus di Malang, Jawa Timur). Habitat.Vol 27(2), 85-93. 